\title{
Data sources on landscape structure in a highly industrialized area
}

\author{
Kinga Mazurek \\ Department of Physical Geography, Faculty of Earth Sciences, University of Silesia, Będzińska Str. 60, 41-200 Sosnowiec, Poland \\ E-mail address: mazurek.kingaa.@gmail.com
}

\begin{abstract}
Landscape may be described as a part of space characterized by a certain physiognomy, which is a dynamic system subject to evolution. An important factor influencing the type and condition of the landscape is human activity which shapes or rebuilds its structure. Interesting results may be obtained on comparison of archival cartographic materials with contemporary studies and zoning plans. The Upper Silesian Coal Basin is a region with a clearly transformed landscape. The determinant of the geographical environment transformation here is the anthropogenic factor. The study area includes the upper part of the Kłodnica catchment (229.6 sq km). The study is a review, and its aim is to systematize data sources used in the research on the transformation of landscape structure of a heavily industrialized area. In the first half of the nineteenth century created the "Urmesstischblätter" in the scale of 1:25 000. Afterwards preparations began to take new topographic images of the country (the "Messtischblätter"). In the 1990s initiated the development of a new topographic map (in the scale of 1:10 000). Recent data source is for example the project CORINE Land Cover 2006. There are many of various sources of data on land cover. An important aspect is the proper selection of documents and maps, and their proper interpretation.
\end{abstract}

KEY WORDS: topographic map, landscape structure, land use, the Kłodnica, Upper Silesian Coal Basin

\section{Introduction}

In Polish, the term "landscape" was probably first applied by Joachim Lelewel in the first half of the nineteenth century, and it was popularized by Wincenty Pol (PIETRZAK, 2005). This concept can be interpreted in multiple ways. The manner of understanding this term depends on the discipline of science, as well as tools and research methods applied. The concept of "landscape" frequently appears in geographic and biological studies, and also in land management, urban planning and landscape architecture. Landscape can be analysed in terms of physical geography, geochemistry of landscape, in a geobotanical depiction, in animal ecology, architecture, or in terms of history and culture (RICHLING \& SOLON, 2011). Focusing on the approach appropriate for physical geography, landscape may be described as a complex system consisting of landforms, rocks, water, soil, vegetation and atmosphere (ZONNEVELD, 1990) or as a part of space characterized by a certain physiognomy, which is a dynamic system subject to evolution which is continuously modified as a result of increasing human activity (RICHLING \& SOLON, 2011). Landscape may be understood as a heterogeneous fragment of an area consisting of ecosystems coupled to each other, wherein each landscape replicates itself in space in a similar form (FORMAN \& GORDON, 1986).

Undeniably, an important factor influencing the type and condition of the landscape is human activity which shapes and, in some places, completely rebuilds its looks and structure. In this way, a cultural landscape is formed, which is a historically shaped piece of geographical space, formed by a fusion of environmental and cultural impacts, which create a specific structure and is distinguished by a peculiar physiognomy (MYGAPiĄTEK, 2001).

Among a multitude of definitions some common elements may be found - a coherent image of components that are repeated in space. Therefore, when describing the landscape, all details and components should be taken into account, such as topography, hydrographic network and water reservoirs, land cover and land use structures. Each of these factors varies continuously 
in time and thus the entire landscape structure is subject to evolution. In this aspect, the right approach is to examine the structure of the landscape in terms of chronostructure. Interesting results may be obtained on comparison of archival cartographic materials with contemporary studies and zoning plans. An important aspect is the proper selection of documents and maps, and their proper interpretation. A wide time range covered in source materials allows for the creation of an analysis with a complex time frame.

The Upper Silesian Coal Basin (USCB) is a region with a clearly transformed landscape. The determinant of the environment transformation here is the anthropogenic factor. In this area, the transformation of the landscape is contributed to by: the discovery and intensive exploitation of natural resources (coal, iron ore, lead and zinc ores), manufacturing industries (iron, metallurgical plants, coking), the energy industry, the chemical industry, transportation and the development of new technologies. The discovery of raw materials and the study of processing technologies have influenced the development of settlements and the influx of migration from other parts of the country. The Upper Silesian (Katowice) conurbation has been formed.

Visible transformations take place within river basins located in mining areas. A comparison of archival and current states of landscape in the area of research and observation of contemporary transformations allows for a precise description of transformations (MAZUREK, 2014a).

\section{Aims and methods}

Undoubtedly, the landscapes of towns incorporated in the Katowice conurbation have been continually transformed as a result of activities carried out there. The study area is an eminent example in the region of a place with distinct landscape transformations. The described fragment of the Kłodnica catchment is located in the Silesian voivodeship (the former Katowice voivodeship), and also in the eastern part of historic Upper Silesia. This area has always been the focus of a lot of attention of authorities, due to its strategic importance for mining and heavy industry. Access to considerable energy resources influences the region's prominent position both in the country and in Europe. Reliable measurements have been carried out and cartographic records have systematically been created, so this area is one of the best mapped areas. Silesia has been included on general maps, topographic maps and thematic maps such as geological, economic, industrial, historical or national.

The study is a review, and its aim is to systematize data sources used in the research on the transformation of landscape structure of a heavily industrialized area. The specificity of the zone covered in the study allows for interesting observations, including changes in the use and land cover in the catchment areas located in the Upper Silesian Metropolitan Union.

\section{The study area}

The study area includes the upper part of the Kłodnica catchment - from its source to the estuary of the Bielszowice Stream to Kłodnica. It has been determined based on the 2nd watershed of the Kłodnica, on the basis of the 1:50 000 hydrographic map of Poland. This area consists of $229.6 \mathrm{sq} \mathrm{km}$ and includes 6 elementary catchments of the following rivers: Promna (21.88 sq km), Ślepiotka (14.00 sq km), Kokociniec (4.67 sq km), Jamna (22.94 sq km), Jasienica (72.40 sq km) and the Bielszowice Stream (32.75 sq km) and the direct watercourse area of the very river of Kłodnica (a total of $61.31 \mathrm{sq} \mathrm{km}$ ) (MAPA HYDROGRAFICZNA POLSKI, 2001). The study area includes parts of the cities of Chorzów, Gliwice, Katowice, Mikołów, Ruda Śląska, Swietochłowice, Zabrze and the counties of Gliwice and Mikołów (Fig. 1). The examined part of the catchment is clearly anthropogenically transformed.

The Kłodnica is a right tributary of the Oder. The sources of the river are located at an altitude of about 305 meters above sea level in Katowice, on the border of the districts of Brynów and Ochojec, and its mouth on the Oder River is located at an altitude of about 164 meters above sea level in the city of Kędzierzyn-Koźle (HoŁDA, 1995). The entire course of the river has a length of $84 \mathrm{~km}$. The Kłodnica stretch that flows through the study area measures 23.56 kilometres. In the examined section, the river flows from the east to the west (almost latitudinal) in a regulated bed fortified with fascine. In several places, the Kłodnica has a complete sewage infrastructure (NOCOŃ ET AL, 2006). On the border of Katowice and Ruda Śląska, the river has retained its natural character (Fig. 2) with numerous meanders and oxbow lakes, and its valley covered by extensive wet meadows, reed beds and marshes. The Kłodnica headwaters area has been protected since 2001 as a valuable piece of landscape in the form of a nature-landscape complex of the "Kłodnica Sources" (UchwaŁa Rady MiejSKIEj Katowic, 2001). 


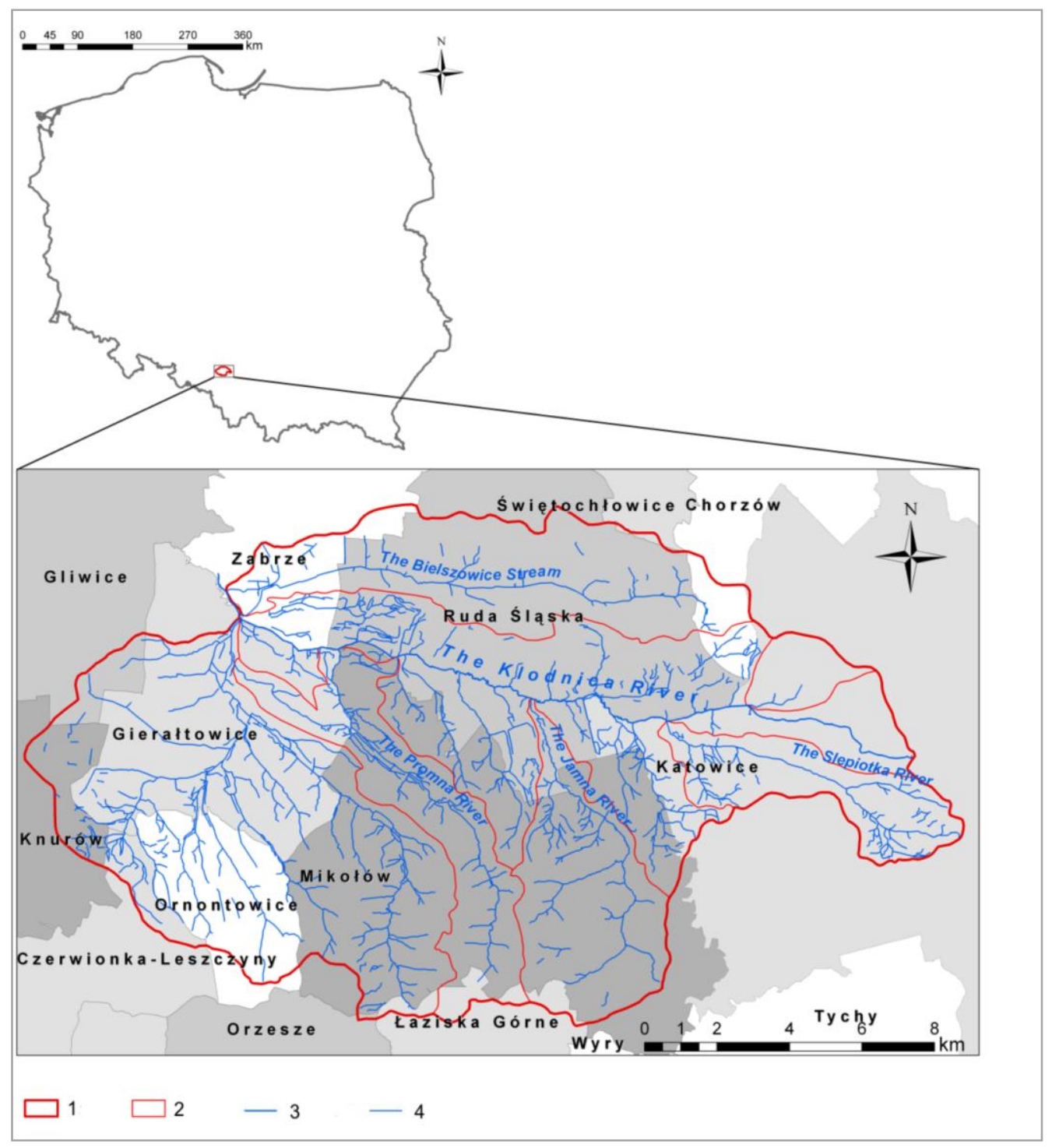

Fig. 1. Location of the upper part of the Kłodnica catchment

1 - border of research area; 2 - elementary catchment borders; 3 - Kłodnica river; 4 - Kłodnica's tributaries

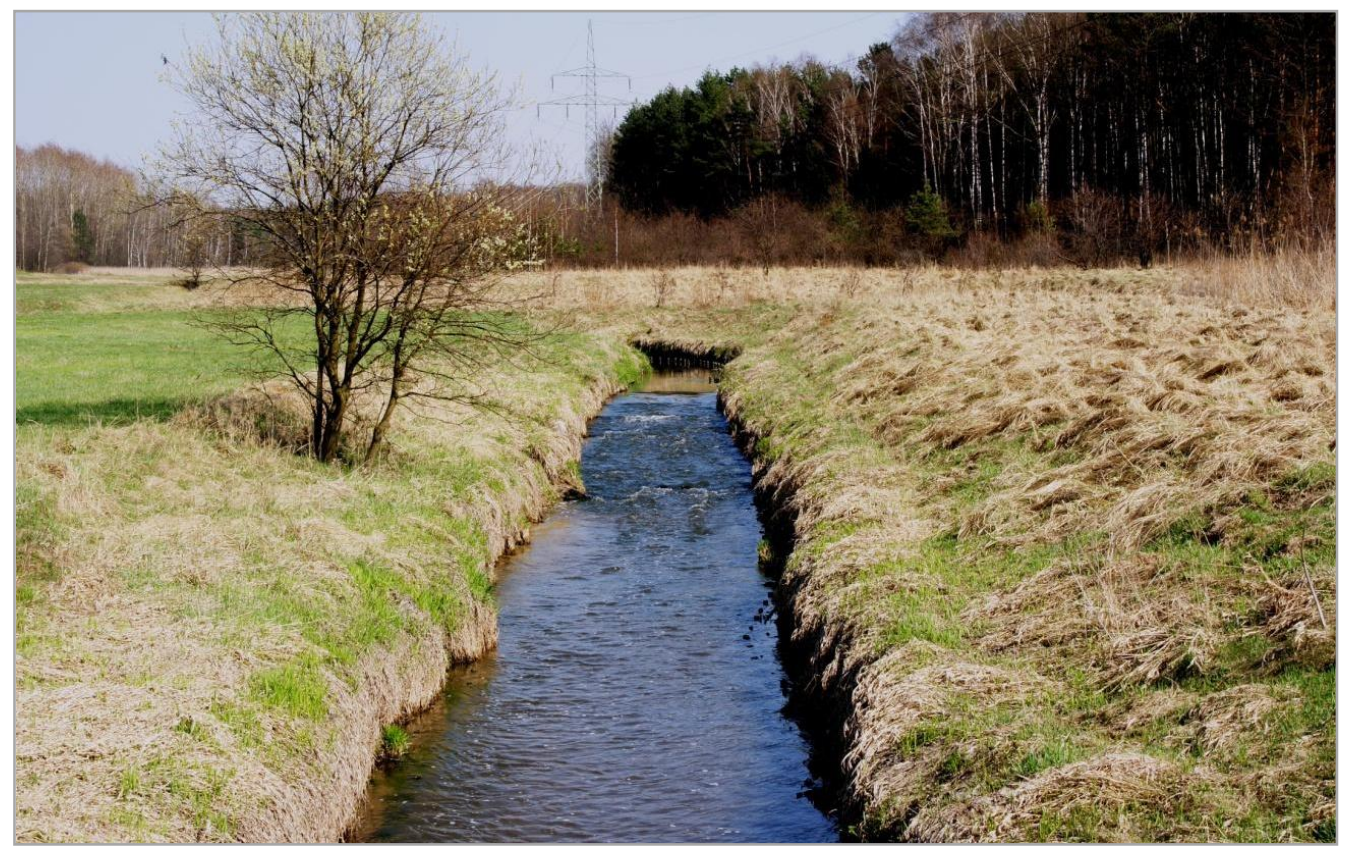

Fig. 2. Kłodnica's riverbed in the city of Ruda Śląska (K. Mazurek) 
The area covered by the study is a part of the Katowice conurbation and the Upper Silesian Metropolitan Union. According to the physical geography division by KONDRACKI (2002), this area is a part of the Silesian Highlands macro-region (341.1) and the Katowice Upland mesoregion (341.13). This region is primarily built with Carboniferous sandstone and shale covered with tertiary clay, sandstone and claystone as well as quaternary sediment (KONDRACKI, 2002). The studied part of the catchment is located in the western part of the Bytom and Katowice Plateau, and in the eastern area of the Raciborz Basin (KARAśBRZOZOWSKA, 1960). The prevailing relief has a horst and graben structure established as a result of Hercynian and Alpine tectonic movements. The landscape consists of plateaus, bottoms of basins and valleys which are typical for uplands (GILEWSKA, 1972; PEŁKA-GoŚCINIAK \& SZCZYPEK, 2008). The relief has been strongly modified by industrial activity (mainly coal mining), and urbanization taking place in this area.

The pedosphere in this area consists mainly of acidic and podsolic soils, formed of sand, clay and loess, hydrogenic soils, marshy and muddy soils as well as anthropogenic soils (industrial and urban soils), present in areas heavily transformed by human (DOBRZYŃSKI ET AL., 1999).

The area is covered mostly with mixed forests such as: red oak (Quercus rubra), birch (Betula pendula), pine (Pinus sylvestris), larch (Larix decidua), aspen (Populus tremula L.) and alder (Alnus glutinosa). In the studied zone, numerous species of synanthropic and nitrophilous vegetation are represented. Also here, except for the protected nature and landscape "Kłodnica Sources" complex, there are also other natural areas: in the Ślepiotka Valley, a floral nature reserve "Ochojec", a forestry nature reserve "Las Murckowski", a nature and landscape complex "Uroczysko Buczyna" on the border of Katowice and Ruda Śląska, a nature and landscape complex "Dolina Jamny" and numerous wetlands, flood plains and ponds.

\section{Archival cartographic materials}

\section{4a. The first half of the nineteenth century}

In the eighteenth century, due to the Prussian King Frederick II the Great, Silesia was incorporated into Prussia. This province gained in importance and became an important economic region of Prussia. Deposits of coal and heavy metal ores were located here, an innovative, "Silesian" method of production of zinc was developed, followed by an intensive development of industry, and German colonization. Administrative reforms were carried out by Prussian authorities (ZŁOTY, 2007). In the first half of the nineteenth century, numerous, and scattered small coal mining companies were established which extracted in a simple way, mainly using bed outcrops (MAZUREK, 2014b). Cleared areas appeared near small mines, which often became the core of a future settlement (URMESSTISCHBLÄTTER, 1827).

Silesia was covered in direct topographical photographs in several time frames. In the period 1816-1830, plane tabling topographic images were made with the use of a measuring table, which captured the area of the entire state of Prussia. The "Urmesstischblätter" was developed, i.e. topographic maps based on triangulation, in the scale of 1:25 000. The "Urmesstischblätter" was performed based on instruction by gen. Carl Friedrich Freiherr von Müffling, head of the General Staff (Konias, 2010). The area of Upper Silesia was measured in the years 1824-1828, and it consisted of 134 sections. Materials belong to the Collections of the State Library in Berlin - Prussian Cultural Heritage (THE STAATSBiBliotheK Zu BERLIN PREUSSISCHER KULTURBESiTZ).

Original, colourful sheets developed in the years 1816-1830, despite their simplicity of presentation of the topographic situation, were characterized by a high qualitative distinction between objects, and illustrated the basic knowledge on geographical environment and landscape (Fig. 3). The notations were presented on two exemplary sheets. Among the elements depicted in the "Urmesstischblätter" you can find:

1) linear objects: roads (divided in terms of categories and surface), rivers, creeks, streams, canals;

2) area objects: plant cover (dry and wet meadows, marshes and swamps, pastures, forests, wilderness), water reservoirs, buildings (cities, small towns, villages, farms);

3) linear signatures: boundaries (of province, regencies, districts), locks, bridges, moats;

4) point signatures: buildings (individual houses, churches, chapels, offices, farms), industrial and economic facilities (factories - 13 different signatures, mines - 13 signatures for different minerals, water mills - 10 types, windmills -3 types, tunnels) and others (crosses, boundary stones, trees, hills, telecommunications equipment, triangulation points) (SCHARFE, 1972).

In the years $1840-1850$ on the respective sheets the newly created railway line WrocławMysłowice was manually applied. Maps were prepared using the following inks and colours: black ink, carmine ink (purple shade), gamboge 
dye (a faint, dark golden colour), indigo ink (blue and violet shade), roasted umbra ink (warm, dark brown colour), cinnabar ink (signal red shade), and copper patina dye (bright cold green). Most of the applied dyes had low durability. The only ones resistant to the test of time are the roasted umbra and cinnabar (which darkens with time)
(URMESSTISCHBLÄTTER, 1827). Von Müffling's relief shading was used to visualize the relief on the map, although this method was retired in favour of a contour line method (izohipse). In addition, data was reported in Prussian units (feet and rods), even though the metric measure had already been in use (KoniAs, 2010).

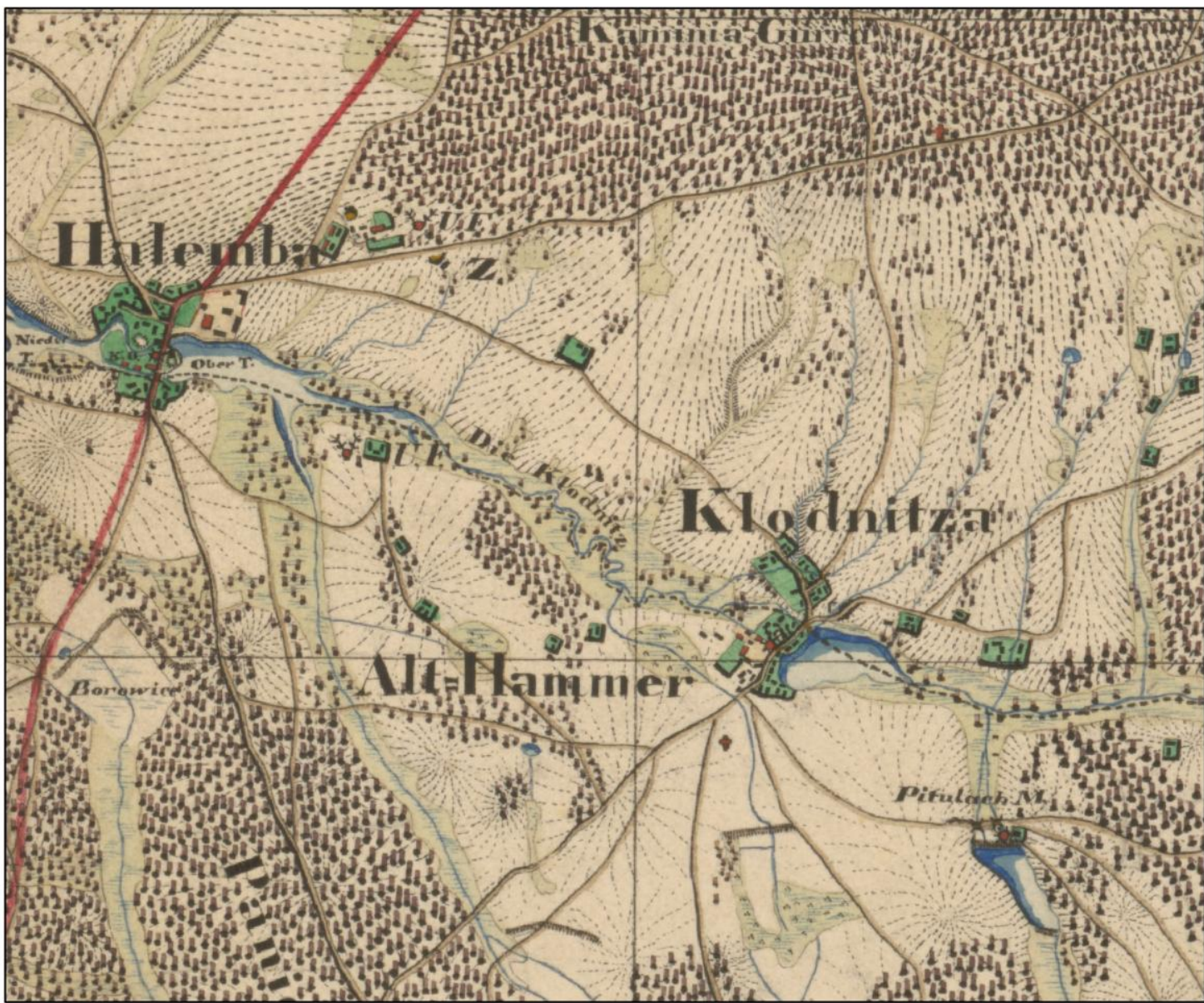

Fig. 3. Fragments of Urmesstischblatt, sheet Swietochowitz no. 3353, draw-up year 1827 with the consent of The Staatsbibliothek zu Berlin - Preussischer Kulturbesitz (owner of the originals)

\section{4b. The second half of the nineteenth century}

Silesia still belonged to the German state, the German Empire (in 1871, the Prussian king was crowned the Emperor of united Germany). Mining activities intensified, which resulted in the colonization of forest areas and formation of farms. The mines merged with neighbouring mining fields, which, in turn, affected the concentration of production, the development of facilities and the increase in the depth of exploitation (MAZUREK, 2014b). In the vicinity of industrial plants, housing estates developed. Buildings lost their rural character. The landscape of Upper Silesia clearly transformed near the towns of
Mikołów, Gliwice and Bytom, with the emerging mine shafts, steel mills, and factory chimneys. The first anthropogenic forms such as gangue waste, post-steelworks waste and mine pits emerged. Transportation routes were developed (MesstischblätTER, 1883; ZŁOTY, 2007).

After successive reforms of the Prussian cartography, preparations began to take new topographic images of the country (the measurements were taken in the period 1858 to 1888). Photos in the scale of $1: 25000$ were compiled through plane tabling by using topographic steering. They were based on a new, thickened triangulation network and levelling. They became the basis for the German State 
reference map and, in contrast to the previous tabling photo editing, they were published (JANKOWSKI, 1961; KRYŃSKI, 1970; SZAFLARSKI, 1965). The legend of the map is more complex, and it presents the following objects (Fig. 4):

1) linear objects: railways ( 6 types), roads (4 types), rivers, creeks, streams, canals;

2) area objects: plant cover (deciduous, coniferous and mixed forests, wastelands, meadows, vineyards, thickets, marshes and bogs, hop-gardens), water reservoirs, buildings, others (Christian and non-Christian cemeteries, depression fields);

3) linear signatures: boundaries, dikes, dams, rocks, walls, fences, ditches;

4) point signatures: buildings, industrial and economic facilities (open and closed mines, a water mill, a water tower, a wind turbine, a mill, a quarry), others (a tomb, a monument, a forestry, a radio station, a chapel, a church, a levelling benchmark, a ruin, a battle site, a trigonometric point) (KonIAS, 2010).

The reproduction of sheets was made with the use of a lithographic method and hydrographic objects were stained blue (ZÖGNER \& ZÖGNER, 1981). The relief was presented by contour lines developed by interpolating points of elevation. The main contour line cutting was every $20 \mathrm{~m}$ (MesstischBlätTer, 1883). The "Messtischblätter" are held by the State Library in Berlin - Prussian Cultural Heritage (The Staatsbibliothek zu Berlin - Preussischer Kulturbesitz), the State Archives in Katowice and at the Wroclaw University Digital Library.

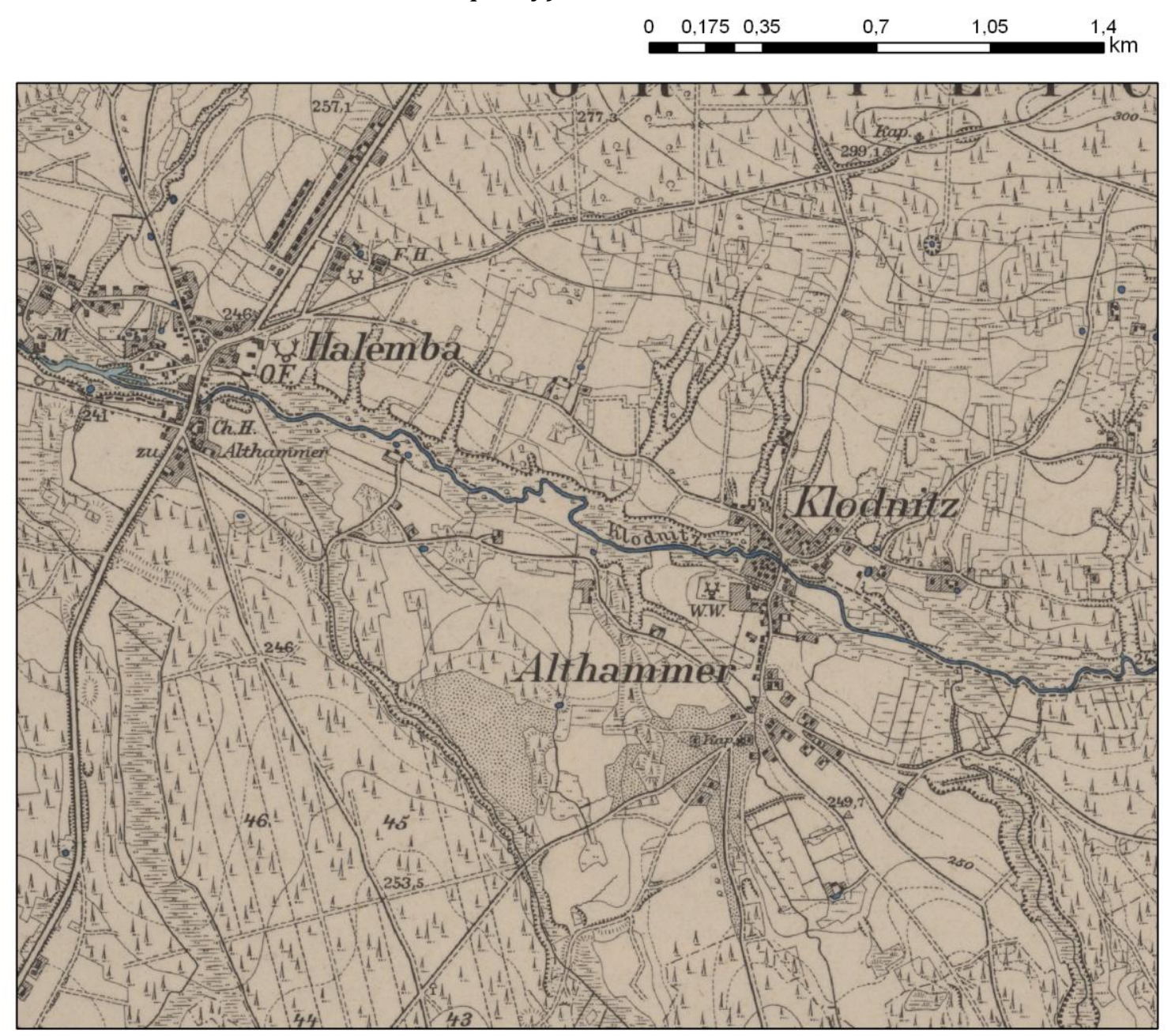

Fig. 4. Fragments of Messtischblätt, sheet Swietochowitz no. 3353, draw-up year 1883 with the consent of The Staatsbibliothek zu Berlin - Preussischer Kulturbesitz (owner of the originals)

4c. The first half of the twentieth century

The beginning of the twentieth century brought about changes in the national situation. Once Poland regained its independence, the people of Upper Silesia were in favour of joining the region to the country, which resulted in three Silesian uprisings in the years 1919, 1920 and 1921 and a national plebiscite in Silesia (20.03.1921). Finally, nearly $30 \%$ of the Upper Silesia was joined to Poland (BAHLCKE ET AL., 2011). A Silesian voivodeship was created from the regained territories and it 
existed throughout the interwar period. The Second World War proved to be ruthless for the whole country, as well as for Silesians.

In the cartographic presentation of Upper Silesia, the medium-scale "Messtischblätter" topographic maps, systematically updated and published until 1944, are still important. Editions published after 1912, are topographical images made with the use of advanced photogrammetry, updating the topographic situation and inventory of field objects (KRÜGER \& SCHNADT, 2000).

Maps were further provided with geographical coordinates, a rectangular coordinate grid (related to the Gauss-Krüger projection). The looks of sheets was slightly modified: on the margins a description of kilometre grid and a deviation of the magnetic needle were included and an extensive legend was printed (KonIAS, 2010). The legend included: transportation and technical infrastructure, hydrography and objects related to it, land cover (vegetation) and its development, buildings (varied by type), administrative boundaries, detailed descriptions of field and topographical facilities, the relief in the form of isolines and letter symbols. In addition, maps had the following annotations: the year of first publication, the year of the map update, the year of addendums and the year of colour edition (MESSTISCHBLÄTTER, 1942). The materials were published in colour (black ink for terrain, brown ink for the relief, blue ink for hydrography). The main contours were marked every $20 \mathrm{~m}$. Among the sheets, there were special "Messtischblätter" ones issued, which constituted only temporary issues. These maps have a "Vorlaufige Ausgabe" annotation on them.

\section{$4 \mathrm{~d}$. The end of the twentieth century}

After the fall of communism, there appeared new priorities such as: the region's development, the introduction of new technologies and remediation of degraded environment. After many years of intensive mining operations, changes in the relief and surface subsidence in mining areas became more evident (MAZUREK, 2014c). Restructuring of mining and heavy industry was essential.

In 1989, an act under the name of a "Geodetic and Cartographic Law" was passed, which appointed the Surveyor General at the National Department of the Surveyor General of the country. The editorin-chief of civil maps, i.e. the Geodetic and Cartographic Service, initiated the development of a new, publicly available topographic map in the scale of 1:10 000, where the "1942" coordinate system was adopted with the Kronshtadt reference level (after 1995, maps were published in the "1992" system). Sheets approved by the Surveyor General were issued between 1993 and 1994. These were based on earlier materials, which were updated. Four-colour maps, characterized by a significant generalization of content compared to previous materials, were issued. The number of symbols was reduced (or modified), the graphics of the maps was changed (MAPA TOPOGRAFICZNA POLSKI, 1994). The legend of symbols and abbreviations included:

1) linear objects: roads, railway and tram lines, water (rivers, streams, canals);

2) area objects: plant cover (forests, groves, parks, thickets and mountain pine scrub, orchards and plantations, allotments, grassy vegetation, wetlands and marshes, wasteland), water reservoirs, cemeteries;

3) linear signatures: administrative boundaries, ravines, slopes, embankments, dykes;

4) point signatures: buildings (public and residential buildings), industrial and utility buildings (industrial and technical buildings), sacral buildings, others (rocks, boulders, caves, trees, geodetic control points and points of elevation, letter symbols).

The relief is illustrated by means of contour lines (main contour lines every $10 \mathrm{~m}$ ). The materials can be found in the Central Institute of Geodesy and Cartography Documentation in Warsaw and Provincial Documentation Centres of Geodesy and Cartography.

\section{Landscape data in the twenty-first century}

The twenty-first century brings new possibilities in obtaining information about the environment and landscape structure. Traditional topographic maps are frequently being replaced by orthophotomaps, numerical terrain models (NTM), a database of topographic, aerial and satellite photos. A noteworthy project among modern data sources is the CORINE Land Cover 2006 (CLC2006). The project aims to document changes in land cover and to collect similar data from all over Europe. This is a continuation of the CLC1990 and CLC2000 programmes created by the European Environment Agency (EEA). In Poland, the executor of the project is the Chief Inspectorate for Environmental Protection in Warsaw. Information provided by the programme includes surface data on land cover and land use, mapped on the basis of a visual interpretation of satellite images from the Landsat, the IRS and the SPOT satellites (http://clc.gios.gov.pl/). Land cover is generated in three hierarchical layers: the first level is the main land cover (anthropogenic areas, forests 
and semi-deserts, areas used for agriculture, wetlands, hydrographic objects), the second level presents 15 classes of land cover (suitable for maps in the scales of 1: 500000 to 1: 1000000 ), the third level comprises 44 precisely defined categories.

Data may also be obtained directly from resources collected by the satellites. The National Aeronautics and Space Administration (NASA) and the United States Geological Survey (USGA) conduct a programme for remote acquisition of Landsat images of Earth, within which the Landsat 8 satellite operates. This satellite was launched into space on 11.02.2013 and it moves in orbit at an altitude of $705 \mathrm{~km}$ and has two remote sensing instruments: the Operational Land Imager (OLI) and the Thermal Infrared Sensor (TIRS) ( http:// landsat.usgs.gov/).

The actual, current method of land use must be compared with the plans for use or conversion of land. It can be done by examining the strategy for development and zoning plan as well as the study of conditions and directions of development for a municipality developed by individual municipalities and approved by city councils. The content of a zoning plan is regulated by the Ustawa z dnia 27 marca 2003 r. o planowaniu $i$ zagospodarowaniu przestrzennym. The plan should include information on the allocation of land, terms and conditions for the release of land plots and information on borders of protected areas.

\section{Summary}

Interesting sources of information that reflect the state and structure of the landscape in the area covered by the research have been described. Materials present the picture of the geographical environment from the 1820s to the first decade of the 21st century, making it possible to make an interesting and extensive analysis which clarifies the changes in the landscape structure. Data sources are mostly topographic maps (years 1827-1994). Prussian and German cartographic materials are undeniably a source of knowledge about the nineteenth-century landscape and forms of land use by humans. Important publications describing the formation and the correct interpretation of the content of the map include the Urmesstischblätter and the Messtischblätter. Polish maps, in the scale of 1:10 000, on the other hand, show the image of the region in the period of industrial restructuring. More recent data have a completely different character. Knowledge about landscape structure may be obtained from contemporarily ongoing projects: the CORINE
Land Cover 2006 (CLC2006) and the Landsat. The above combination shows that there is a proliferation of various sources of data on land cover. Due to their different form and content, a choice must be made to use the most appropriate materials for the issue in question.

"The entity responsible for implementation of the CLC2006 project in Poland is the Chief Inspectorate for Environmental Protection, acting as the National Focal Point for cooperation with the EEA. The direct contractor of work was the Institute of Geodesy and Cartography. The funds earmarked for the domestic CLC2006 project came from sources of the European Environment Agency and the National Fund for Environmental Protection and Water Management."

\section{References}

Bahlcke J., Gawrecki D., Kaczmarek R. 2011. Historia Górnego Śląska. Polityka, gospodarka i kultura europejskiego regionu. Dom Współpracy Polsko-Niemieckiej. Muzeum Śl., GliwiceKatowice.

Dobrzyński B., Konecka-Betley K., Kuźnicki F., Zawadzki S. 1999. Mapa gleb Polski 1:2 000 000. PWRiL, Warszawa.

Forman R.T.T., Gordon M. 1986. Landscape Ecology . J. Wiley and Sons, New York.

Gilewska S. 1972. Wyżyny Śląsko - Małopolskie. [in:] Klimaszewski M. (ed.) Geomorfologia Polski. T. 1. Polska południowa - góry i wyżyny. Wyd. PWN. Warszawa: 232339.

Hołda I. 1995. Hydrologiczne aspekty ochrony wód powierzchniowych na przykładzie zlewni Kłodnicy. Mat. ze spot. warsz. „Czysta Kłodnica”. UM Ruda Śląska. Ruda Śląska (unpublished).

Jankowski W. 1961. Niemiecka mapa w skali 1:25 000 na terenach polskich na wschód od Odry i Nysy. Prz. Geod., 33(11): 417-462.

Karaś-Brzozowska C. 1960. Charakterystyka geomorfologiczna Górnośląskiego Okręgu Przemysłowego. Biul. Kom. do Spraw GOP PAN, 37, Warszawa.

Kondracki J. 2002. Geografia regionalna Polski. Wyd. Nauk. PWN, Warszawa.

Konias A. 2010. Kartografia topograficzna państwa i zaboru pruskiego od II polowy XVIII do połowy XX wieku. Wyd. Nauk. Akad. Pomor., Słupsk.

Krüger G., Schnadt J. 2000. Die Entwicklung der geodätischen Grundlagen für die Kartographie und die Kartenwerke 1810-1945. Berlin-Brandenburg im Kartenbild. Berlin: 26-49.

Kryński S. 1970. Z dziejów triangulacji na ziemiach Polski. Triangulacja pruska 1832-1914. Stud. i mat. z dziejów polskiej nauki, Ser. C, 14. Wyd. PWN. Warszawa.

Mapa hydrograficzna Polski 1:50 000, sheets: M-34-62-A, M34-62-B, M-34-62-C, M-34-62-D, M-34-63-A, Gł. Geodeta Kraju, Warszawa, 2001.

Mapa topograficzna Polski 1:10 000, sheet: M-34-62-B-c-2, Gł. Geodeta Kraju, Warszawa, 1994.

Mazurek K. 2014a. Landscape structure changes in the Slepiotka River drainage basin in the period 1824-1993 (The Silesian Upland, Poland). Contemporary Trends in Geosci., 3: 32-40.

Mazurek K. 2014b. Rozwój górnictwa węgla kamiennego w Rudzie Śląskiej od XVIII wieku do czasów współczesnych. $Z$ bad. nad wpt. antropopresji na środ., 15: 71-79.

Mazurek K. 2014c. Wpływ eksploatacji węgla kamiennego na ukształtowanie powierzchni wybranych fragmentów 
miasta Ruda Śląska w latach 1975-2011. Acta Geogr. Silesiana, 15: 13-30.

Messtischblätter 1:25 000, sheet: 3353, Berlin, 1883.

Messtischblätter 1:25 000, sheet: 5779, Berlin, 1942.

Myga-Piątek U. 2001. Spór o pojęcie krajobrazu w geografii i dziedzinach pokrewnych. Prz. Geogr., 73(1-2): 163-176.

Nocoń W., Kostecki M., Kozłowski J. 2006. Charakterystyka hydrochemiczna rzeki Kłodnicy. Ochr. środ., 28(3): 39-44.

Pełka-Gościniak J., Szczypek T. 2008. Główne rysy rzeźby obszaru Górnośląskiego Związku Metropolitalnego i jego przekształcenia. [in:] Dulias R., Hibszer A. (eds.) Górnośląski Związek Metropolitalny. Zarys geograficzny. PTG Oddz. Kat., Sosnowiec: 34-42.

Pietrzak M. 2005. Ewolucja poglądów geograficznych na krajobraz. [in:] Maik W., Rembowska K., Suliborski A. (eds.) Geografia jako nauka o przestrzeni, środowisku i krajobrazie. Podstawowe Idee i Koncepcje w Geografii, T. 1, Łódź.

Richling A., Solon J. 2011. Ekologia krajobrazu. Wyd. Nauk. PWN. Warszawa: 221-238.
Scharfe W. 1972. Abriß der Kartographie Brandenburgs 17711821. Veröffentlichungen der Historischen Kommission zu Berlin, 35. De Gruyter. Berlin.

Szaflarski J. 1965. Zarys kartografii. Wyd. II. Wyd. PPWK. Warszawa.

The Staatsbibliothek zu Berlin - Preussischer Kulturbesitz http://www.preussischer-kulturbesitz.de/ (02.12.2014).

Uchwała Rady Miejskiej Katowic, Nr XXXIV/453/01 z dn. 26 kwietnia $2001 \mathrm{r}$.

Urmesstischblätter 1:25 000, sheet 3353, Berlin, 1827.

Ustawa z dnia 27 marca 2003 r. o planowaniu i zagospodarowaniu przestrzennym.

Złoty A. 2007. Vademecum historyczne Górnego Śląska. Wyd. Koral. Pszczyna: 5-29.

Zögner L., Zögner G. K. 1981. Preußens amtliche Kartenwerke in 18. Und 19. Jahrhundert. Ausstellung und Katalog. Inst. f. Angew. Geodäsie. Berlin.

Zonneveld J. I. S. 1990. Introduction to "Cultural aspect of landscape". First Inf. Conf. of the IALE Working group "Culture and Landscape", Svobodova Ed. H. (ed.), Wageningen.

http://clc.gios.gov.pl/ (access 13.12.2014).

http://landsat.usgs.gov/ (access 12.12.2014). 